\title{
MOBILIDADE URBANA SUSTENTÁVEL PARA A CIDADE DO RIO DE JANEIRO
}

\author{
Lourdes Zunino Rosa*, Cecilia Herzog*, Ricardo Esteves ${ }^{* * *}$
}

\begin{abstract}
*Arquiteta urbanista (UP 6, Paris 1983), Mestrado em Conforto Ambiental (M.Sc.,UFRJ, 1992) e Doutorado em Engenharia de Transportes (D.Sc., UFRJ, 2007), consultora e professora em temas relacionados a Conforto Ambiental, Economia de Energia e Mobilidade Sustentável.

lourdes.zunino@gmail.com
\end{abstract}

\begin{abstract}
"Administradora de empresas (Universidade Cândido Mendes, 1981), paisagista (Universidade Veiga de Almeida, 2005), Mestrado em Urbanismo (M.Sc., FAU/UFRJ, 2009), Presidente do Inverde - Instituto de Estudos, Pesquisas e Projetos em Infraestrutura Verde e Ecologia Urbana, consultora e professora de temas relacionados a Infraestrutura Verde, Ecologia Urbana. ceciliapherzog@gmail.com

***Arquiteto urbanista (FAU/UFRJ, 1980), Mestrado em Engenharia de Transportes (M.Sc.,UFRJ, 1985) e Doutorado em Engenharia de Produção (D.Sc., UFRJ, 2003), professor de disciplinas e consultor em temas relacionados a Planejamento Urbano, Planos Diretores e Mobilidade Sustentável. ricardo.esteves@globo.com
\end{abstract}

\section{RESUMO}

A cidade do Rio de Janeiro foi escolhida como sede de importantes eventos esportivos, tendo a oportunidade de constituir um legado de mobilidade urbana visando à sustentabilidade. Este artigo traça historicamente a busca de soluções para o desenvolvimento urbano, e apresenta levantamento de diretrizes, atributos, características e critérios da mobilidade urbana sustentável, ilustradas com exemplos de boas práticas. Questiona-se se as transformações em curso e projetadas para a cidade atendem às diretrizes preconizadas.

Palavras-chave: Mobilidade sustentável, planejamento urbano, infraestrutura verde, urbanismo, sustentabilidade. 


\title{
SUSTAINABLE URBAN MOBILITY FOR THE CITY OF RIO DE JANEIRO
}

\begin{abstract}
The city of Rio de Janeiro has been chosen to host important sports events, what made feasible the opportunity to create a legacy of urban mobility aiming sustainability. This article traces historically the search for solutions to urban development and shows survey guidelines, attributes, characteristics and criteria of sustainable urban mobility, shown with examples of good practice. It is questioned whether the changes currently adopted and projected to town, meet the recommended guidelines.
\end{abstract}

Key words: Sustainable Mobility, Urban Planning, Green Infrastructure, Urbanism, Sustainability.

\section{INTRODUÇÃO}

O Rio de Janeiro passa por momento de investimentos expressivos, por conta dos grandes eventos esportivos programados para os próximos anos, como uma das cidades da Copa do Mundo de Futebol de 2014 e sede dos Jogos Olímpicos de 2016. Desde que sua candidatura a sede dos Jogos foi aceita, em outubro de 2009, uma série de propostas relacionadas à mobilidade, algumas já executadas ou em execução, geram questionamentos e expectativas.

O que é mobilidade urbana sustentável e como situá-la historicamente? Quais suas diretrizes, atributos, características e critérios? O quanto avançamos, e o que se espera, como legado dos eventos esportivos para a cidade do Rio de Janeiro?

Atualmente, uma mobilidade bem mais próxima da sustentabilidade já é realidade em várias cidades, como Bogotá, Amsterdam, Copenhage, Freiburg (Alemanha), Paris, Londres, Seul e Nova York. O processo de mudança de paradigma, de transporte individual para o de massa, deixou de ser utópico para se tornar realidade, em cidades de todos os portes. No entanto, muitas cidades do mundo convivem com problemas relacionados à mobilidade, como congestionamentos, acidentes, poluição ambiental, distribuição desigual do espaço viário entre seus usuários, especulação urbana, sedentarismo e suas consequências. O modelo vigente nesses ecossistemas urbanos, centrado em meios individuais, reforça o egocentrismo na percepção e gestão das 
cidades, ao mesmo tempo em que engole os espaços públicos, reduzindo as amenidades e, por consequência, a atratividade das vizinhanças à presença de seus moradores e visitantes. Moradores, trabalhadores e visitantes pedestres foram, historicamente, sendo empurrados para os lados, para o espaço remanescente da calçada, cada vez mais desvalorizada, no sentido de se atender às demandas por espaço para as circulações motorizadas, especialmente de automóveis particulares.

Por razões concretas, referindo-se, por exemplo, ao consumo de combustíveis e perda de tempo, entre outros custos, mas também por razões intangíveis (ainda), como a capacidade de oferecer espaços para convivência, discussões e fortalecimento das organizações sociais, o atual modelo de circulação tornou-se caro, social e ecologicamente impactante, e precisa ser repensado e alterado. Estudos desenvolvidos em São Paulo dão conta de custo (generalizado) do congestionamento diário, da ordem de $\mathrm{R} \$ 34$ bilhões por ano, muito maior do que o investimento necessário para a maioria dos sistemas públicos coletivos. Ao mesmo tempo, pesquisas realizadas pela LSE (London School of Economics) estimam a economia (positiva) atualmente girada pelo uso da bicicleta como sendo de $£ 3,3$ milhões, com custos econômicos, sociais e ambientais bem menores do que os impostos atualmente pelo tráfego motorizado.

Segundo Lester Brown, fundador e pesquisador do "The WorldWatch Institute" instituto de pesquisa privado, sem fins lucrativos, destinado à análise das questões ambientais globais -, o processo de urbanização motivado pela atração urbana é impulsionado pela falta de oportunidades no campo. Na maioria dos países em desenvolvimento, esse fluxo das zonas rurais excede a capacidade de os centros urbanos proporcionarem emprego, habitação, eletricidade, água, esgotos e serviços sociais, provocando o surgimento de favelas, onde multi-

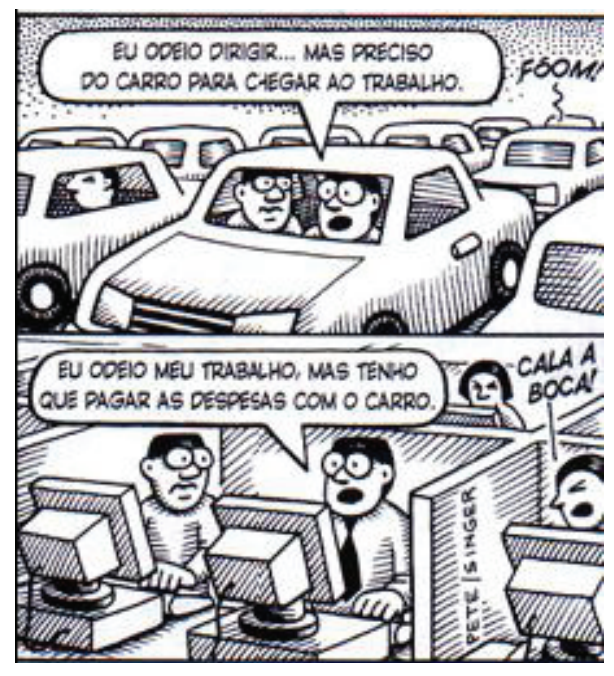
dões convivem sob condições marginais e degradantes. "Cidades são lugares dinâmicos, cheios de vida e oportunidades, mas também podem ser sujas, violentas, superpopulosas. Hoje representam $2 \%$ da superfície da terra, mas usam $75 \%$ de seus recursos" (BROWN, 2003).

Nas cidades, cada vez maiores, mais populosas e com sistemas de transporte público deficitários,

Figura 1: Círculo Vicioso (LUDD, 2004) 
o automóvel tornou-se símbolo de status, já que, frequentemente, representa a opção mais confortável de deslocamento, criando um círculo vicioso. Quanto mais aumentam as distâncias e os custos, aumenta também o interesse pelo automóvel, que é estimulado, pois representa igualmente trabalho e renda.

O desenho do cartunista Singer retrata com humor a situação.

\section{MOBILIDADE URBANA SUSTENTÁVEL: A BUSCA DA CIDADE IDEAL}

O site do Ministério das Cidades introduz a Política Nacional da Mobilidade Urbana ${ }^{1}$, com a seguinte definição²:

"A Mobilidade Urbana Sustentável pode ser definida como o resultado de um conjunto de políticas de transporte e circulação que visa proporcionar o acesso amplo e democrático ao espaço urbano, através da priorização dos modos não-motorizados e coletivos de transportes, de forma efetiva, que não gere segregações espaciais, socialmente inclusiva e ecologicamente sustentável."

Já o Victoria Transport Policy Institute3 afirma que não há definição universal de sustentabilidade, desenvolvimento sustentável ou transporte sustentável, e lista algumas definições, dentre elas, a da Conferência Europeia de Ministros de Transporte, em 2004:

"Um sistema de transporte sustentável é aquele que é acessível, seguro, amigável ao meio ambiente, e economicamente viável."

A questão da mobilidade permeia a busca da cidade ideal ao longo do tempo.

1 Lei 12.587, de 3 de janeiro de 2012. Disponível em http://www.planalto.gov.br/ccivil_03/_ato2011-2014/2012/ lei//12587.htm.

2 http://www.cidades.gov.br/index.php/politica-nacional-de-mobilidade-urbana.

3 http://www.vtpi.org/tdm/tdm67.htm 


\section{Busca de Soluções para o Desenvolvimento Urbano}

"As sociedades primitivas opunham-se ao poder arbitrário de um único indivíduo e estimulavam a cooperação em lugar da competição. O planejamento, nesses grupos, diversamente do que viria a suceder em culturas mais adiantadas, tendia para o consenso" (GUIMARÃES, 2004).

O homem se desenvolveu buscando sua sobrevivência. Hoje entende que precisa cuidar também da sobrevivência da natureza em seu entorno, para sua própria perpetuação enquanto espécie. Supõe-se que culturas ainda mais adiantadas conseguirão retomar o consenso, a cooperação necessária para equilibrar o desenvolvimento urbano e o meio ambiente, em busca da sustentabilidade.

Com o desenvolvimento urbano, surge a busca pela cidade ideal. Cidades fortificadas, fundamentadas em critérios somente racionais e geométricos, marcaram época, respondendo aos anseios de defesa do seu momento histórico.

A mobilidade entre as cidades, durante muitos séculos, foi restrita à energia humana e animal. Os impactos ambientais do sistema de transportes não faziam parte das preocupações cotidianas, até o início da revolução industrial, quando o transporte marca o desenvolvimento urbano, por meio das ferrovias.

"A partir de 1840, a estrada de ferro e o capitalismo teriam um desenvolvimento conexo, com a estrada de ferro tornando-se a mais poderosa arma da economia" (GUIMARÃES, 2004). Como consequência, a especulação do solo urbano se acelera, e muitas cidades se tornam insalubres, pela proximidade com as fábricas e com as estradas de ferro. A primeira metade do século XIX seria marcada por protestos contra a sordidez, a sujeira e a miséria.

A reação surge com novos paradigmas de organização das cidades, como o planejamento urbano de Paris, por Hausmann, e de Barcelona, por Cerdá, que derrubam as muralhas medievais da cidade, permitindo sua expansão, com uma malha geométrica inovadora, enquanto sistema viário, e quadras com jardins internos que se comunicam com as ruas, permitindo aeração e iluminação das construções (VALLEJO \& TORNER, 2002). Note-se aqui que o planejamento urbano, na época, buscava privilegiar a ordenação do espaço, eliminando barreiras, para iluminar e ventilar (Sanitarismo). 
Em contraposição ao movimento de expansão das cidades, a reação também se dá na forma de cidades-jardins, comunidades autossuficientes, interferindo no ambiente natural e construído, visando a uma vida mais saudável. Idealizadas com ruas largas e arborizadas, tinham na área central as construções públicas (teatro, museu, administração pública, hospital, galeria de artes), além de terrenos espaçosos para as residências, escolas, igrejas, quadras de jogos, e um cinturão verde envolvendo todo esse espaço. Após o cinturão, estariam o comércio e as indústrias, próximos à estrada de ferro, para facilitar a entrada e saída de mercadorias. Quando a população não pudesse mais crescer de forma ordenada, outra cidade-jardim seria construída, com as mesmas diretrizes, e a implantação de um meio de transporte faria a integração entre as cidades (CHOAY, 1965). Espalharam-se na Europa e nos Estados Unidos, a partir dos anos 1920, mas poucas existem ainda, como Letchworth e Radburn.
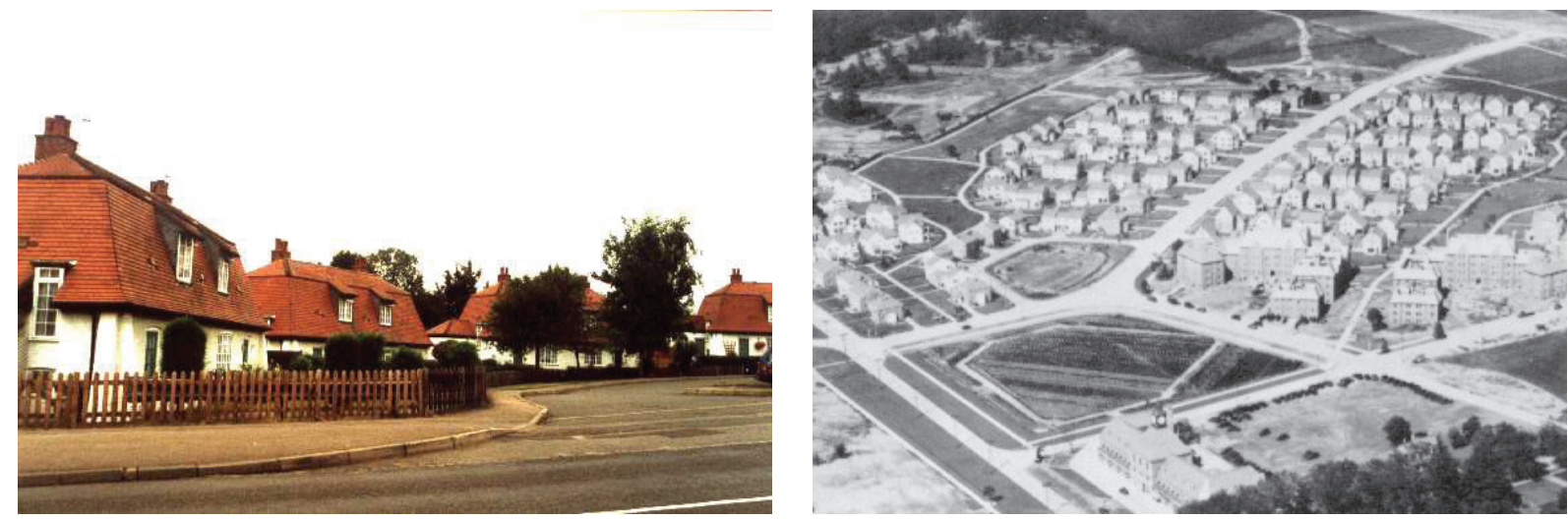

Figuras 2 e 3: Letchworth na Inglaterra e Radburn nos EUA (imagens da web).

Do conceito de cidade-jardim, perdurou até os dias de hoje o conceito de cinturão verde (green belt), que faz parte da política de desenvolvimento sustentável em países da Europa. No Canadá, surgiu na década de 60, para conter o espalhamento das cidades. O sistema é considerado como infraestrutura verde e elemento de organização da mobilidade, visando sustentabilidade.

No início do século XX, a busca da cidade ideal surge com o movimento moderno, funcionalista, empreendido por Le Corbusier, Gropius e outros seguidores, acreditando que um estilo e uma prática internacionalizados ultrapassariam as fronteiras geográficas e temporais, em busca de uma realidade total para a raça humana.

Ao contrário dos blocos de edificações fechadas, planejados em quadras, típicos do movimento de expansão das cidades europeias na segunda metade do século XIX, 
os novos princípios de organização sugerem grupamentos de edificações abertas. Os quatro princípios que sustentam o funcionamento da cidade são: habitar, trabalhar, cultivar o corpo e o espírito e circular com relação a essas atividades. O zoneamento, com sua segregação espacial, se consolida como condição de eficácia funcional da cidade moderna. A nova concepção de cidade é justificada na Carta de Atenas (manifesto urbanístico resultante de Congresso Internacional de Arquitetura Moderna, realizado em Atenas, em 1933):

A cidade não é mais do que uma parte do conjunto econômico, social e político que constitui uma região; o crescimento da cidade devora incontrolavelmente suas periferias verdes, privando os seres vivos de sol, espaço e vegetação; as novas construções em altura deverão situar-se distanciadas entre si, liberando espaços verdes que devem conter construções de uso comunitário ligadas às habitações residenciais; setores industriais devem ser independentes, localizados junto à água, ferrovias e auto-estradas; os centros de negócios deverão se situar na confluência das vias de circulação.

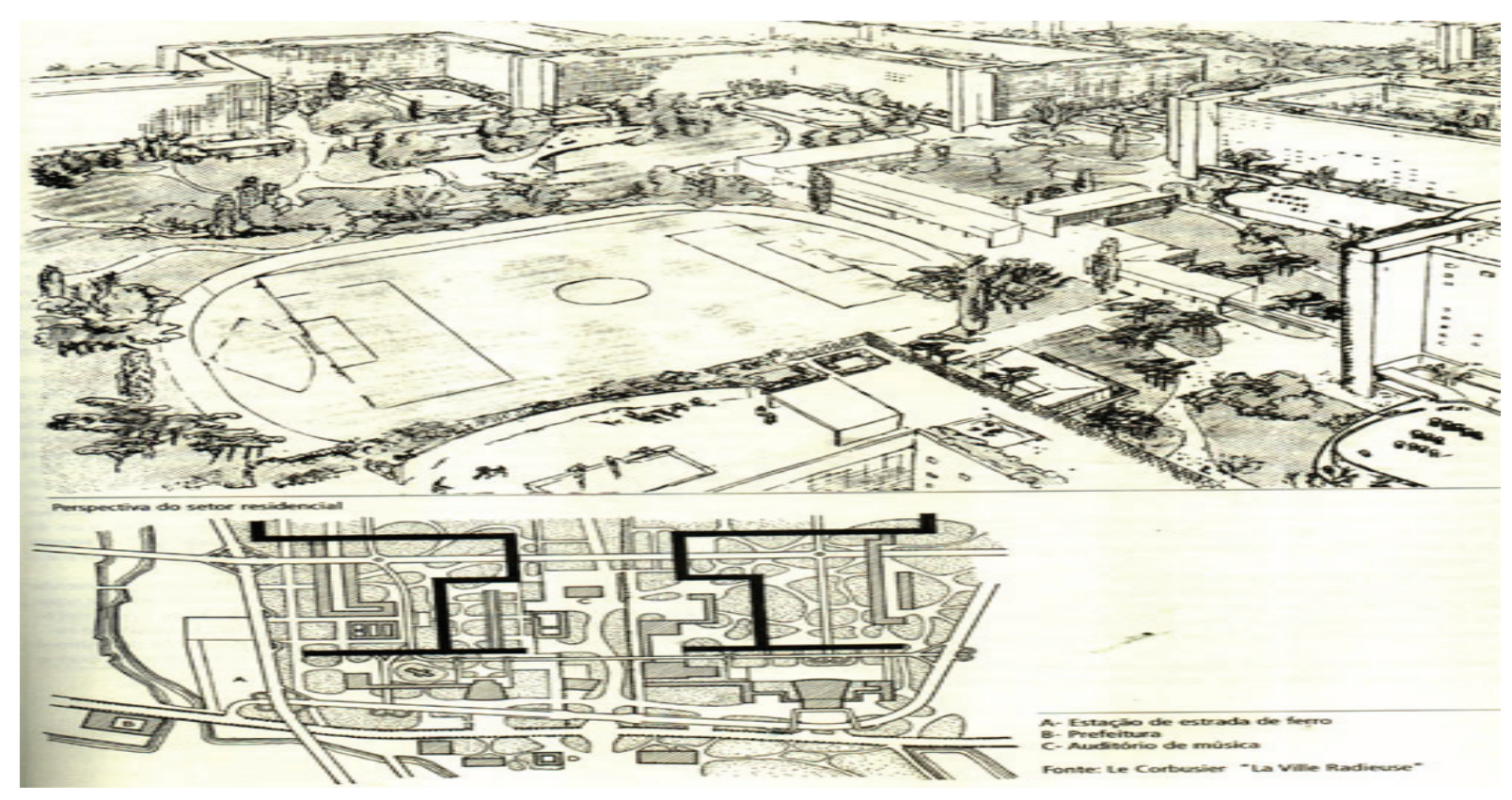

Figura 4 : Projeto Ville Radieuse Le Corbusier (GUIMARÃES, 2004).

A Carta de Atenas torna-se a base para o planejamento internacional das cidades. A imagem do modernismo domina o planejamento urbano do século, mas o caráter da cidade ideal, aos poucos, se perde. Niemeyer e Lucio Costa estão entre os urbanistas 
brasileiros de maior destaque desse período. Fundamentado na energia fóssil necessária para a fabricação de aço, vidro, concreto e, sobretudo, para o deslocamento nas cidades planejadas para veículos motorizados, o estilo internacional não foi superado.

Durante o século $X X$, os impactos ambientais urbanos se propagam, com a mecanização na indústria em geral e com o crescimento e expansão da indústria automobilística em particular. Surgem as highways. Os carros passam a representar conforto e um novo estilo de vida. O ritmo de vida se acelera.

Ivan Illich, teórico em educação, energia e ecologia, em um artigo sobre energia e equidade escrito em 1973, atacou conceitos estabelecidos na época pela sociedade ocidental, afirmando, por exemplo, que os automóveis contribuíam para diminuir a velocidade dos deslocamentos, e que, mais importante do que procurar novas fontes de energia, seria mudar seu consumo (ILLICH, 1973). A favor das cidades compactas, Illich afirma que "existe um lugar para um mundo de maturidade tecnológica. Em termos de circulação, este é o mundo daqueles que ampliaram seus horizontes a treze quilômetros montados em sua bicicleta [...]. A reestruturação do espaço que oferece a cada pessoa a experiência, constantemente renovada, o conhecimento de que o centro do mundo é onde ela vive".

\section{DIRETRIZES, ATRIBUTOS, CARACTERÍSTICAS E CRITÉRIOS}

\section{EXEMPLOS DE BOAS PRÁTICAS}

Diversos autores e instituições listam diretrizes, características e critérios para a mobilidade urbana sustentável (HEIERLI, 1995; LINDQUIST, 1998; ESTEVES, 2003; LITMAN, 2003; COM, 2004; BODMER \& MARTINS, 2005; CRAWFORD, 2006; ITDP 2010). Notaram-se diversas possibilidades de apresentação dos fatores, visando seu êxito. Propõe-se a divisão em três grupos recorrentes: Planejamento e Implantação, Educação e Divulgação, Gerenciamento e Monitoramento (adaptado de ROSA, 2007). Algumas diretrizes foram ilustradas com exemplos de boas práticas:

\section{Quanto ao Planejamento e à Implantação (forma urbana / uso do solo)}

- Criar "zonas ambientais" definidas como unidade territorial, cujo acesso à rede estruturada de transporte da cidade preserve seu interior da necessidade de viagem motorizada e de tráfego de passagem; 


\section{Exemplo de boa prática: Em} Amsterdam algumas áreas residenciais foram projetadas com ruas para crianças. São equipadas com brinquedos, cercas para prevenir acidentes, comodidades como bancos, para supervisão dos pais, e toda sorte de sinalização e restrição a qualquer tipo de transporte (NILSSON, 1998).

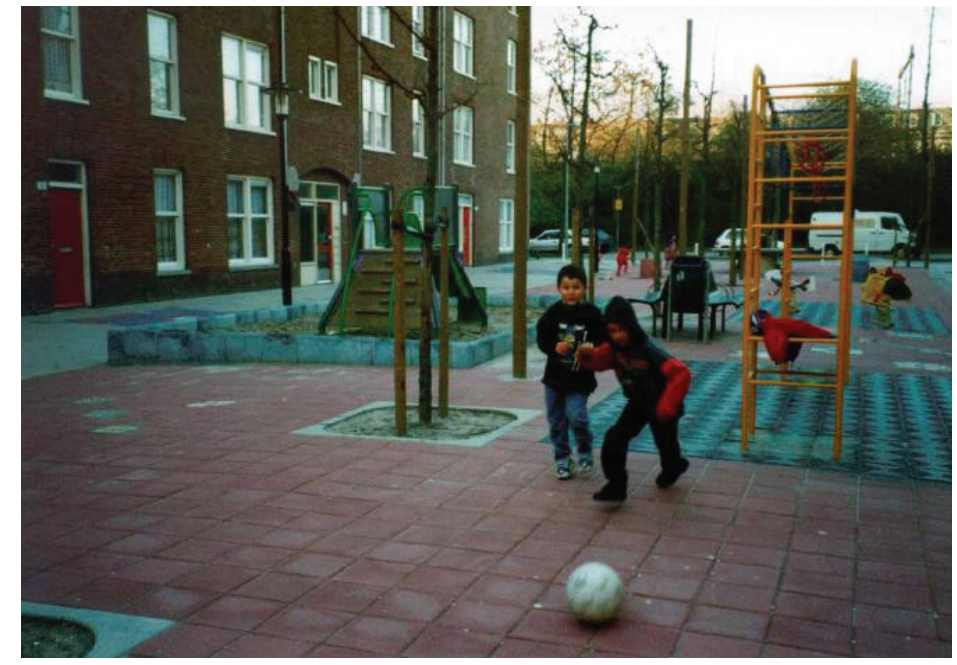

Figura 5: Rua para crianças em Amsterdam (NILSSON, 1998).

- Promover a integração de micro e macro acessibilidade. Promover ligações diretas, privilegiando a mobilidade não motorizada, integrando atividades e localidades;

- Promover a integração do transporte e do uso do solo, por meio da implantação, no interior de polos geradores de tráfego, do embarque e desembarque dos usuários, assim como, prestar informações e vender passagens;

- Ampliar ou implantar sistemas de transporte de alta capacidade, eficientes e de qualidade;

- Buscar a apropriação equitativa do espaço e do tempo na circulação urbana, priorizando os modos de transporte coletivo, a pé, de bicicleta e de pessoas com restrição à mobilidade, em relação ao automóvel particular. Espaços seguros e confortáveis para se andar a pé, ou com transporte não motorizado;

- Promover o reordenamento dos espaços e das atividades urbanas, priorizando investimentos em novos centros, ou reforçando centros de bairro, criando restrições ou reduzindo as necessidades de deslocamento motorizado e seus custos;

- Promover a mistura de usos do solo, maiores densidades urbanas em torno de estações e terminais de transportes públicos, e redes viárias mais conectadas.

Exemplo de boa prática: No sul da Alemanha, a cidade de Freiburg, além de ser um modelo de cidade compacta, que utiliza energia limpa, com prioridade para transpor- 
tes não poluentes, é também exemplo de infraestrutura verde. A articulação dos meios de transporte de baixo impacto pode ser conferida no edifício verde (utiliza energia solar) onde os ciclistas guardam as bicicletas, anexo ao sistema multimodal de transporte, que alia VLT, trens ou ônibus, e que também abriga hotel, comércio, serviços e escritórios, muito próximo ao centro histórico, que fica a uma curta distância, e ao qual os pedestres têm rápido acesso (HERZOG, 2010).
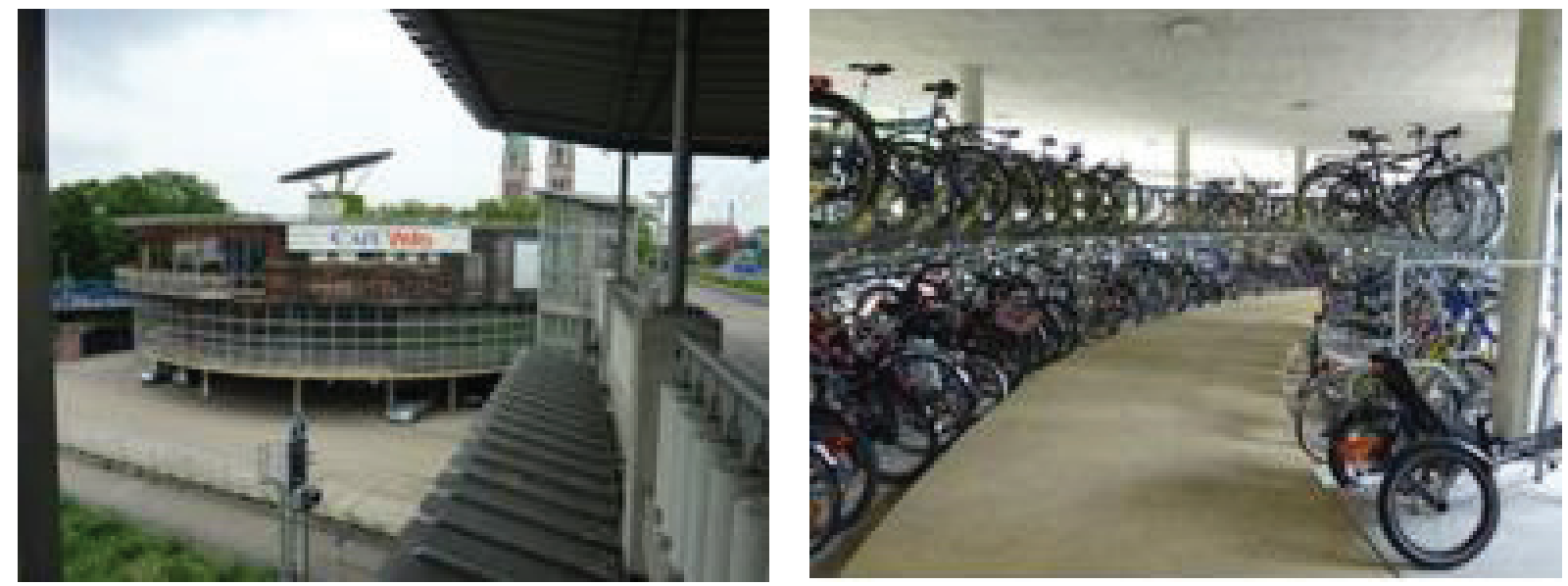

Figuras 6 e7: Freiburg. Vista do edifício garagem de bicicletas e do viaduto por onde passa o VLT. Interior do edifício. Crédito: Cecília Herzog.

- Introdução de medidas de moderação do tráfego (físicas ou de gestão), como estreitamento ou elevação de pista em cruzamentos, redução de velocidade e quantidade de tráfego, tratamento ambiental, como a definição de zonas com prioridade para pedestres e ciclistas, e sinalização de velocidade controlada. Privilegiar zonas residenciais e escolares;

- Criação ou consolidação de caminhos e trilhas em locais propícios;

Exemplo de boa prática: Na França, em Nanterre, área periférica próxima à La Défense, o parque Chémin d'île $e^{4}$ é multifuncional. Centrado em atraentes alagados construídos, que filtram as águas antes de irem para o rio Sena, por eles se pode circular em passarelas e observar os caminhos das águas e a variedade de espécies de flora e fauna presentes no local. Aproveita uma área sob a autoestrada que chega à cidade (HERZOG, 2010).

4 Disponível em http://www.hauts-de-seine.net/cadre-de-vie/protection-environnement/espace-naturel/cheminde-I-ile-promenade-bleue, acesso em 25 de junho de 2010. 


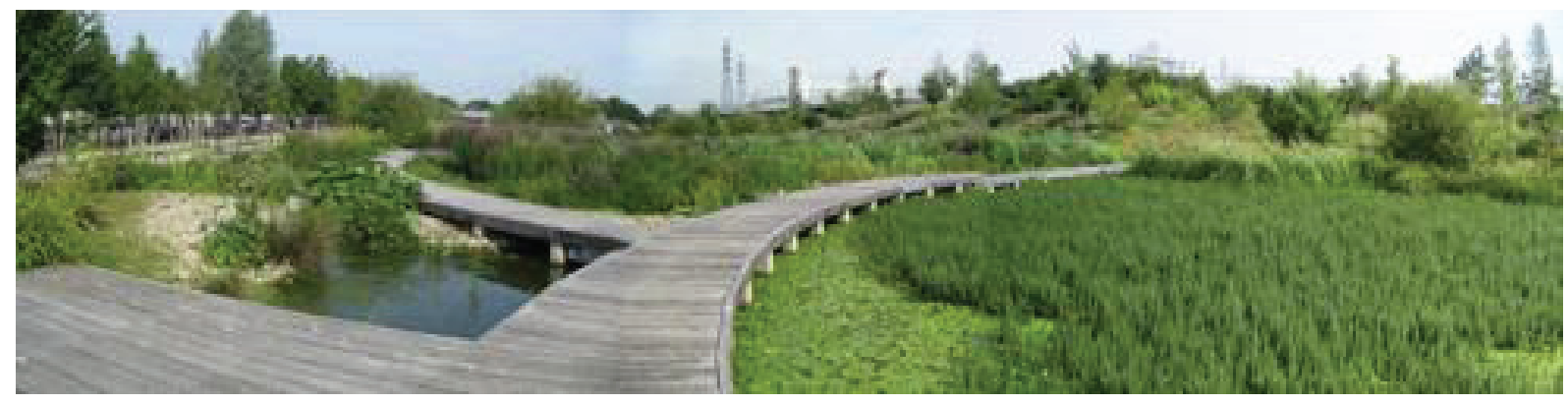

Figura 8: Nanterre, Parque Chemin d'île. Alagado construído. Crédito: Cecília Herzog.

- Projetar novas expansões urbanas, a partir de exemplos bem sucedidos, adaptando-os às condições espaciais, econômicas e sociais do local, incentivando integração e inclusão social;

- Projetar o conforto urbano por meio de arborização, travessias, calçadas e vias para ciclos adequadas ao local de implantação;

- Projetar soluções para estacionamentos dos diversos modais de transporte, visando a equidade;

\section{Quanto à Educação, Divulgação e Pesquisa:}

- Desenvolver campanhas educativas sobre Mobilidade Sustentável, em escolas, associações e mídia, periódica e continuamente;

Exemplo de boa prática: Site do Departamento de Transporte da cidade de Portland, EUA. No item segurança e educação, uma página indica várias maneiras de contribuir para a redução da poluição no ar.

Figura 9: Informação para o Cidadão: Como Contribuir na Redução da Poluição do $\mathrm{Ar}$ (PORTLANDONLINE, 2006).

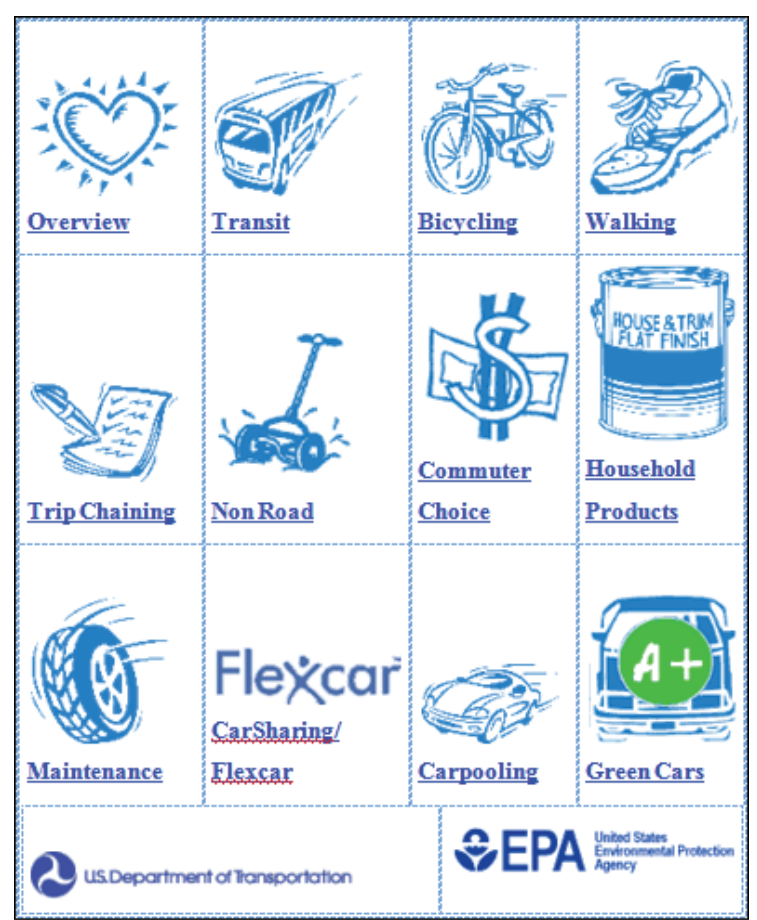


- Criar campanhas educativas, para que os motoristas respeitem os ciclistas e para que os ciclistas respeitem os pedestres;

- Mudar o conceito de bicicleta como artigo de esporte, incentivar empresas a usar a integração metrô-bicicleta como meio de transporte, criar bicicletários em metrôs, e vestiários em fábricas e prédios comerciais, destacando o conceito da saúde para o usuário e para o planeta;

- Envolver a sociedade civil, de maneira geral, na implementação, utilização e monitoramento de medidas visando à Mobilidade Sustentável;

- Ampliar o conceito de transporte para o de comunicação, por meio da utilização de tecnologias relacionadas a telecomunicações e informática, tirando maior partido das infraestruturas existentes;

- Incentivar o uso de sistemas de compartilhamento de automóveis;

- Contribuir para a eficiência energética, desenvolvendo veículos e combustíveis que reduzam consumo e emissão de agentes poluidores, sonoros e atmosféricos;

\section{Quanto à Gestão e Monitoramento:}

- Substituir a lógica da expansão (mais vias), pela gestão e integração (melhores vias para todos);

Exemplo de boa prática: Seul, a capital da Coreia, é uma megacidade em processo de transformação urbana. Apesar da dependência dos automóveis, promoveu a abertura do córrego Cheonggye, que estava coberto por vias e um elevado. A recuperação foi voltada para os usos humanos e a biodiversidade no interior da cidade (HERZOG, 2010).

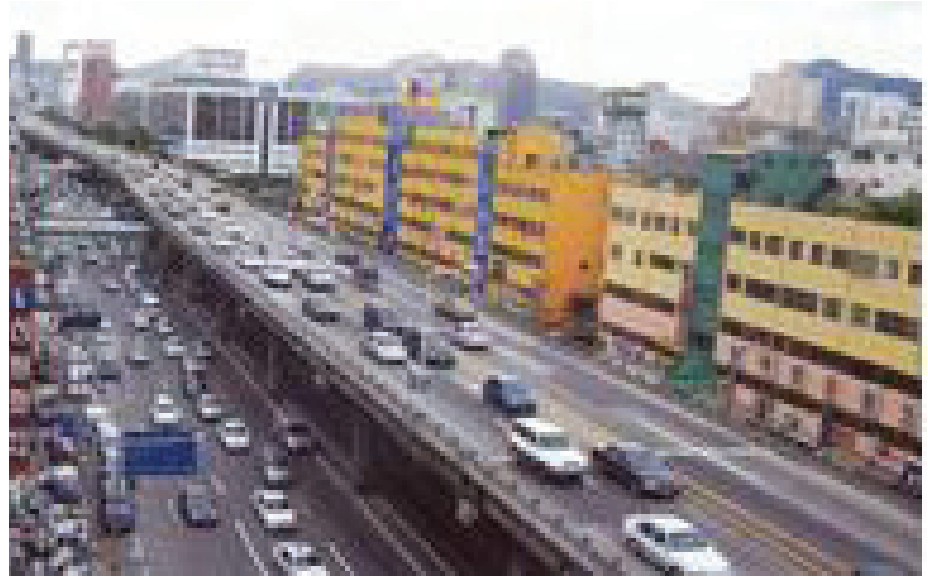

Figura 10. 


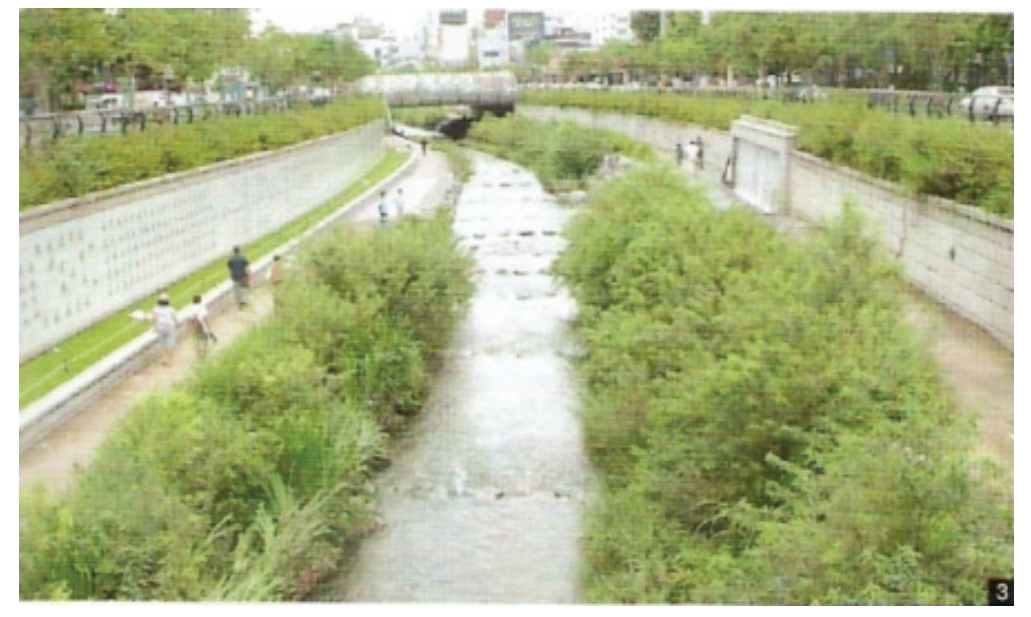

Figuras 10 e 11: Seul, Coreia. Paisagem urbana com o viaduto, modernos edifícios residenciais, cidade orientada para automóveis, anos 1980 e 1990. Rio Cheonggye renaturalizado em 2005, multifuncional, com melhoria da qualidade de vida na cidade. Crédito: Cecília Herzog.

- Tarifar circulação por meio das revisões de controle de poluição e estacionamentos de automóveis particulares, favorecendo o uso de transportes públicos (zonas congestionadas e horário de pico);

- Controlar a poluição do ar e sonora, com multa aos motoristas transgressores e tarifação diferenciada para veículos que poluam menos;

- Incentivar investimentos em transporte público, utilizando energia limpa e controle de ruído;

- Determinar que empreendimentos urbanos de grande porte devam assumir responsabilidade socioambiental, por meio da implantação de planos de mobilidade para seus usuários, respeitando-se os limites de capacidade ambiental;

- Desenvolver o gerenciamento de recursos, que distribua o ônus da mobilidade e garanta a sustentabilidade de seus agentes, a um custo tolerável para os usuários;

- Promover a eficiência e a qualidade nos serviços de transporte público, com apropriação social dos ganhos de produtividade decorrentes;

- Promover a segurança no transporte público e não motorizado;

- Todo novo investimento em transporte motorizado deve prever o mesmo valor investido em transporte não motorizado, acompanhado de análise de custo-benefício e de impactos ambientais e sociais, com consulta pública para avaliação das alternativas; 
- Promover a figura do gestor de mobilidade e a integração entre os diversos atores envolvidos nas ações de gerenciamento;

Exemplo de boa prática: Brugge, na Bélgica, onde as escolas solicitam anualmente a presença de policiais para verificar se as bicicletas dos alunos atendem às normas de segurança. As crianças recebem cartões verdes, se estão de acordo com as normas, ou vermelhos, se a verificação for negativa, tendo o compromisso de atender aos itens em desacordo. ${ }^{5}$

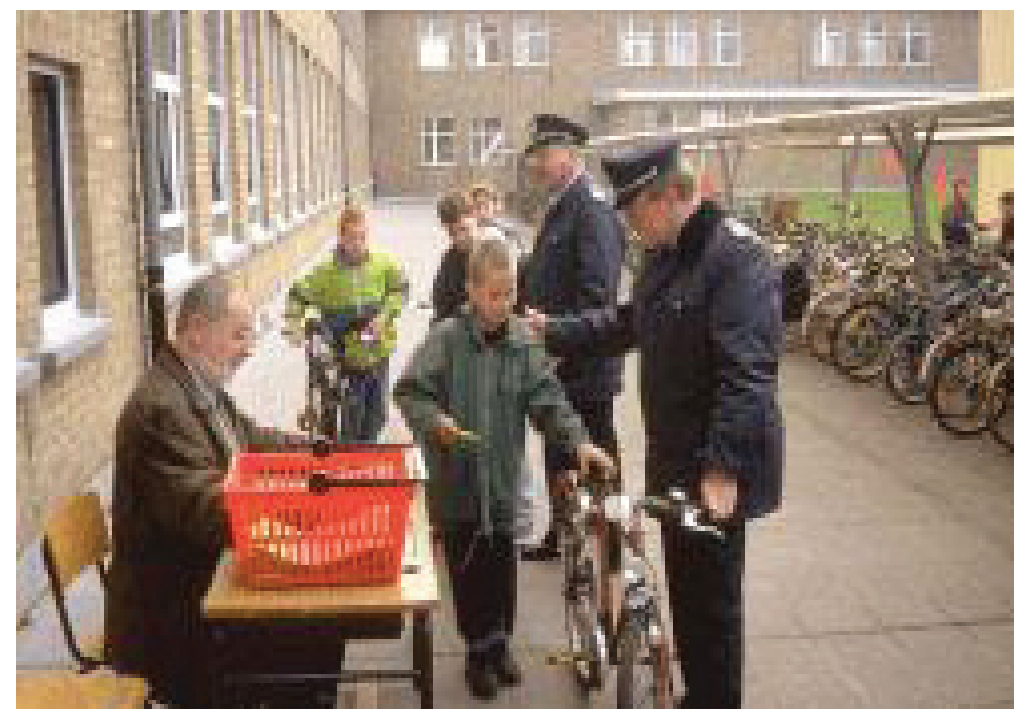

Figura 12: Gestão de mobilidade em escolas em Brugge (NILSSON, 1998).

- Fixação de objetivos quantificados a curto, médio e longo prazo, com um sistema de acompanhamento eficaz.

- Preservar, defender e promover, nos projetos e políticas públicas voltadas ao transporte público e à circulação urbana, a qualidade do ambiente natural e construído e o patrimônio histórico, cultural e artístico das cidades;

- Nas reformas e expansão do espaço urbano, promover o uso de materiais e tecnologias locais, ambientalmente amigáveis e duráveis, reduzindo manutenção;

- Gerenciar o transporte de carga, incentivando o transporte marítimo, fluvial e ferroviário.

5 Apesar de tão longe da realidade recente do Rio de Janeiro, é um exemplo que pode ser adequado para a polícia pacificadora carioca. 
Esta é uma classificação circular, já que todos os itens implicam ações de planejamento, implantação e de gestão. Além do fato de que todas as recomendações poderão ter maior chance de sucesso, se forem aplicadas a partir de ações educativas, com monitoramento para sua possível melhoria, de acordo com cada situação.

Sabe-se que muitas das diretrizes listadas dependem de variáveis locais (geográficas, sociais e econômicas), para que se obtenha êxito na mobilidade sustentável. No entanto, neste levantamento, percebeu-se uma afinidade, na maioria das propostas, entre especialistas de vários países.

Ainda que políticas sobre mobilidade no Brasil sejam recentes, a própria existência da Secretaria Nacional da Mobilidade (SEMOB), desde 2004, com objetivo de promover a mobilidade sustentável, já constitui uma mudança de rumo no setor de transportes, diversificando o foco, que, até então, somente priorizara a indústria automobilística. Espera-se que esta indústria aos poucos se transforme, para atender ao transporte público de qualidade, continuando a gerar renda e trabalho.

\section{LEGADO DOS JOGOS OLÍMPICOS NO RIO DE JANEIRO}

Quais dessas diretrizes, características e critérios estão planejadas, ou sendo executadas, para a cidade do Rio de Janeiro? A seguir, levantamento de notícias e fatos sobre o tema, comentados pelos autores deste artigo.

No portal da prefeitura do Rio de Janeiro, destaca-se, como legado mais significativo, a implantação do sistema BRT (Bus Rapid Transit) e do Programa Morar Carioca (urbanização de favelas). A promessa é que todas as favelas cariocas estejam urbanizadas até 2020 , e que os usuários de transporte de alta capacidade passem de $18 \%$ para $63 \%$, quando os quatro corredores de BRT estiverem prontos ${ }^{6}$.

O Morar Carioca tem grandes chances de pôr em prática a cultura participativa, e espera-se que a política de remoções da população de baixa renda não continue a repetir a má prática de conjuntos habitacionais longe de seus locais de origem e sem a infraestrutura adequada aos dias atuais. Espera-se, também, que considerem con-

6 http://www.rio.rj.gov.br/web/guest/exibeconteudo?article-id=3308728 
ceitos de arquitetura bioclimática e de paisagismo integrado à natureza do entorno, visando qualidade de vida, com redução no consumo de energia.

O sistema de BRT vai reduzir a emissão de gases de efeito estufa, à medida que efetivamente seja reduzida a frota de ônibus da cidade. No entanto perde-se a oportunidade de um investimento maior em transporte sobre trilhos, que beneficiaria parcela mais significativa da população carioca.

Um fato relevante aconteceu durante a construção da linha de BRT Transoeste, no trecho que corta a Barra da Tijuca e Recreio dos Bandeirantes, ao longo da Av. das Américas. Ciclistas invadiram as pistas antes da inauguração, para seus deslocamentos diários. Novas ciclovias não fizeram parte dos investimentos para o local, fato que poderia ter sido revertido, se práticas de participação em Conselhos Municipais de Políticas Públicas fossem estimuladas, para se tornarem realidade.

Quanto à linha de BRT em operação, constatou-se a circulação de ônibus superlotados em horário de pico, enquanto outros vazios esperam o horário de partida no terminal Alvorada, apontando problemas de gestão.

Ainda sobre o BRT, não foram, até o momento, considerados os fluxos naturais que ocorrem na paisagem, e as pistas da Transoeste têm sofrido alagamentos constantes, em chuvas mais fortes, com a retenção das águas, que impedem a circulação. No caso da bacia de Guaratiba, a dinâmica das águas que descem do maciço e alimentam o manguezal, foi alterada. Como resultado, tem causado impactos no grau de salinidade que mantém a ecologia do manguezal. Esse processo está sendo estudado por pesquisadores da UERJ que atuam na área. ${ }^{7}$

Estão previstos também a expansão do metrô até a Barra da Tijuca e a implantação de VLT (veículo leve sobre trilhos) na área central da cidade, conectando a Vila da Mídia, na área do porto, ao aeroporto doméstico e outros sistemas de transporte. Perde-se a oportunidade de ligação sobre trilhos, do aeroporto internacional da cidade a outros modais de transporte. Está prevista uma das linhas do BRT para atender o aeroporto internacional.

7 Entrevistas com Dr. Mario Soares, professor pesquisador de manguezais, do Departamento de Oceanografia da UERJ (maio de 2012). 

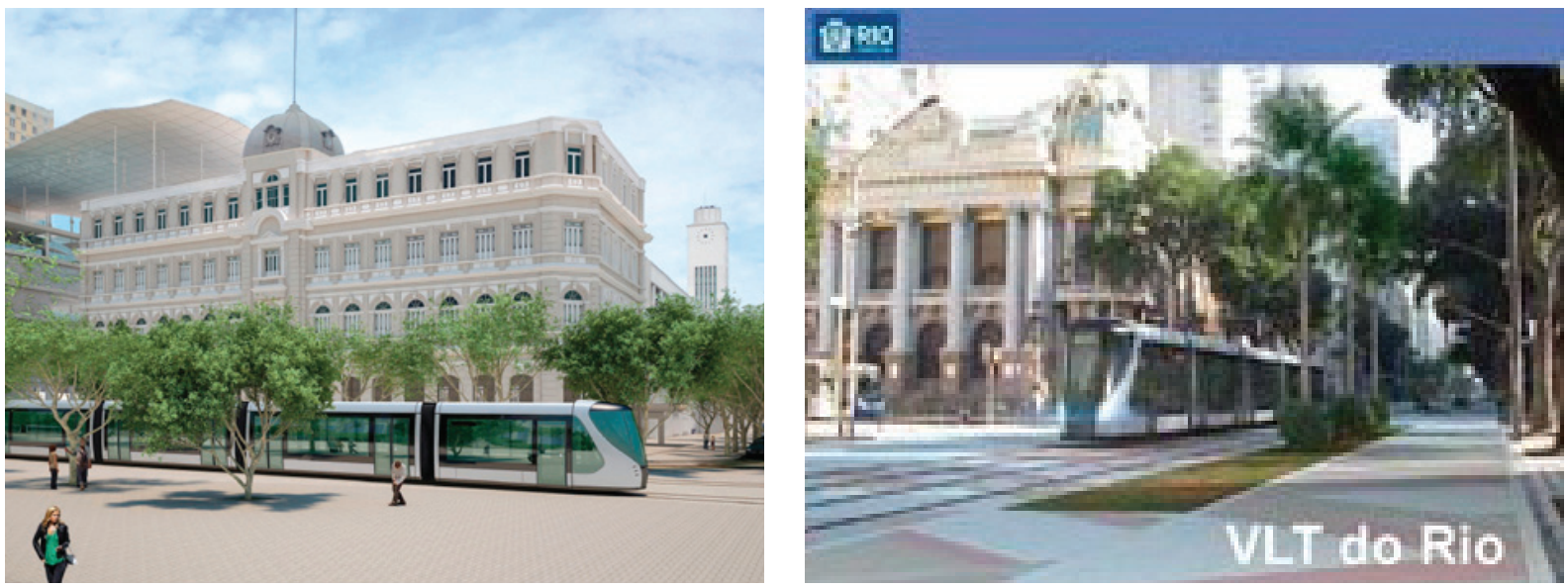

Figuras 13 e 14: Montagem gráfica da implantação do VLT na Praça Mauá e na Av. Rio Branco. Fonte: http://www.portomaravilha.com.br/web/esq/projEspVLT.aspx
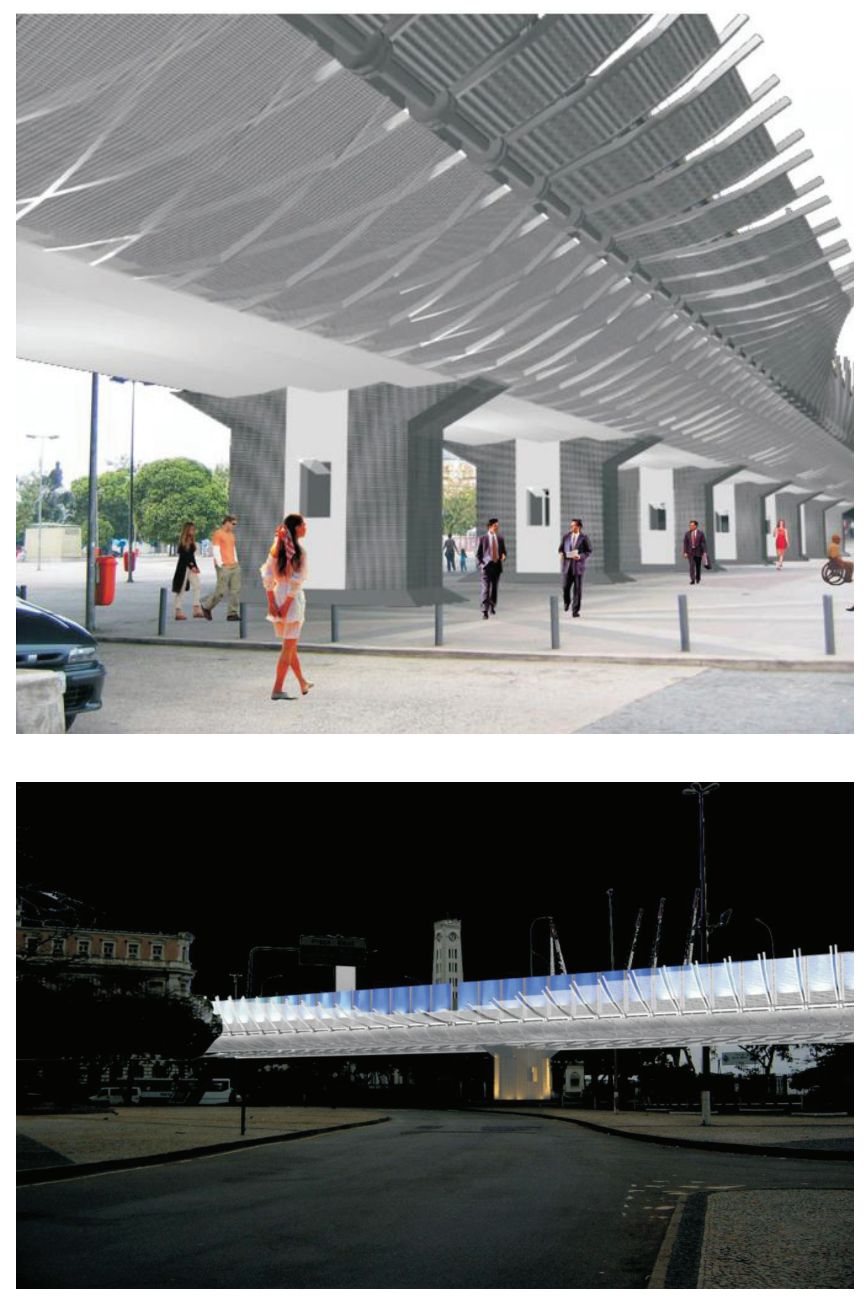

Conforme o site oficial do Porto Maravilha, a previsão é de que a primeira etapa de instalação do VLT seja concluída em 2014, com duas linhas em funcionamento. As outras quatro entram em operação até 2016. Já o portal da prefeitura informa, em notícia de 21/06/2012, que a licitação para implantação do sistema deveria ser concluída em 30 de setembro, mas, procurando nos avisos de licitação disponíveis até dezembro de 2012, não foram encontradas referências ao VLT.

Quanto ao Porto Maravilha, uma questão polêmica divide opiniões: a demolição da Av. Perimetral, que liga

Figuras 15 e 16: Projeto do Arquiteto Ricardo Kawamoto, vestindo a perimetral com tratamento acústico e estético. Um calçadão coberto pela avenida privilegiaria os deslocamentos a pé ou de bicicleta, ligando as ciclovias já existentes na orla ao porto revitalizado. Imagens de acervo da equipe vencedora. 
o centro da cidade a Niterói, Av. Brasil e linha Vermelha, vias com fluxo diário intenso (140 mil veículos/dia, segundo o engenheiro Fernando Mac Dowell). A demolição tem apoiadores, que defendem o caráter estético, pois, construída em várias etapas, ela não tem uniformidade e enfeia a paisagem. No entanto, em 2004, a prefeitura organizou um concurso para solucionar este problema e também tratar a via acusticamente. A solução vencedora foi para a gaveta, com uma mudança de gestão. Era tecnicamente funcional e passaria a valorizar a paisagem.

Ainda como alternativa à demolição, orçada em 2010 em $\mathrm{R}$ 1,2 bilhão, uma equipe de alunos e pesquisadores, liderada pelo professor Cristovão Duarte, da Faculdade de Arquitetura e Urbanismo da UFRJ, desenvolveu um projeto de monorail, uma aplicação bem mais eficaz para a verba destinada à demolição.
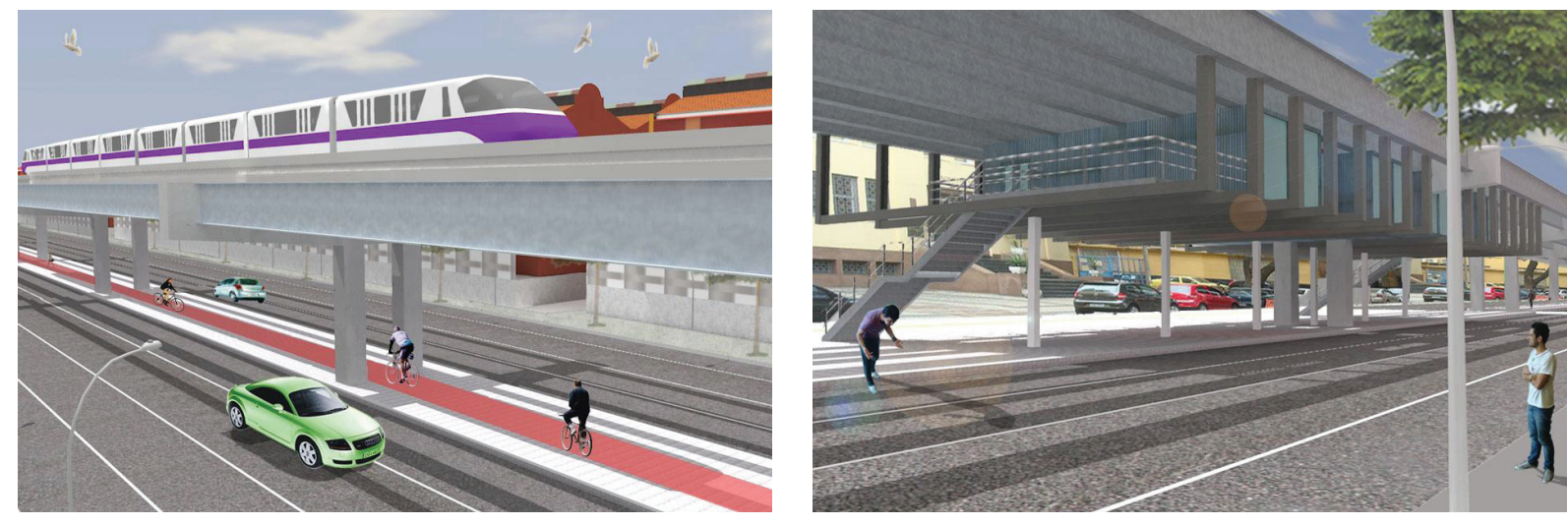

Figuras 17 e 18: Monorail proposto para a Av. Perimetral. Fonte: edição 309 da revista da UFRJ - Olhar Virtual, agosto de 2010.

Algumas tentativas foram feitas, por meio de debates e abaixo-assinado, para entrar com ação civil contra a demolição, até que a sociedade pudesse se manifestar de maneira mais democrática. Nos dias 16 e 17 de maio de 2011, foi realizado um seminário para debater essa questão de importância capital para o destino da área portuária. No entanto os resultados não foram levados em consideração pelos tomadores de decisões. ${ }^{8}$ Atualmente, são apenas reclamações na seção de cartas do jornal O Globo, e eventuais manifestações de técnicos, preocupados com futuros engarrafamentos ainda

8 O seminário Porto Maravilha: Desafios e Problemas foi realizado no auditório do Instituto Histórico e Geográfico Brasileiro (IHGB), com apoio do Prourb-UFRJ, e o próprio IHGB. O vice-prefeito e secretário do Meio Ambiente participou, juntamente com pesquisadores e profissionais que atuam na área. 
mais graves que os atuais. A falta de transparência e participação efetiva da sociedade civil organizada tem marcado o ritmo das propostas de intervenção urbana e obras relacionadas aos grandes eventos, sem um planejamento integrado de longo prazo.

O projeto do Porto Maravilha inclui a construção de um túnel (mergulhão), para substituir a Perimetral. Como a região foi construída sobre aterro, o túnel será parcialmente submerso, e terá reforços para suportar o elevado, até que fique totalmente pronto, permitindo a demolição do elevado e encarecendo ainda mais a obra.

Com conclusão prevista para 2015, deverá ser o terceiro maior túnel do Rio de Janeiro, com $1.800 \mathrm{~m}^{9}$ e prováveis alagamentos. ${ }^{10} \mathrm{Um}$ dos pontos mais inquietantes é a manutenção de investimentos no modelo rodoviarista, antagônico à mobilidade sustentável, com expressivas quantias de dinheiro público. Apesar de previstas parcerias público-privadas, no dia 31 de outubro de 2012, o prefeito do Rio de Janeiro negociou com o governo federal o aumento da capacidade de endividamento da cidade. ${ }^{11}$

Ainda no Porto Maravilha, todos os novos empreendimentos seguem a legislação urbanística, com obrigatoriedade de vagas. Uma garagem com 900 vagas sob a Praça Mauá será também construída. Prédios de até 50 andares são esperados na região, certamente com andares exclusivos para automóveis.

Em nome da mobilidade urbana sustentável e da saúde da população carioca, é tempo de mudança no Código de Obras, para permitir que regiões servidas por transporte público tenham isenção de obrigatoriedade de vagas, e que as construtoras assumam custos de infraestrutura para melhorar a qualidade do transporte público e a acessibilidade em geral na região em que implantam novas demandas. Este, sim, seria um legado transformador.

Outro local que, em princípio, receberá o legado dos Jogos Olímpicos é o bairro de Deodoro. Está prevista nova infraestrutura de centros comerciais e de lazer, assim

9 http://extra.globo.com/noticias/rio/tunel-para-substituir-perimetral-ficara-pronto-em-2015-mas-especialistasrecomendam-cautela-3317550.html

10 Deve ser considerado o aumento do nível do mar, que deverá se intensificar e atingir essa área, que é vicinal à Baía de Guanabara. Haverá necessidade de bombeamento de águas constante, no caso de chuvas.

11 Conforme notícia da rádio CBN, na tarde de hoje, dia do fechamento deste artigo. 
como o Parque Radical, instalação que receberá algumas competições $^{12}$. Uma linha de BRT passará no local.

Atualmente, Deodoro tem uma estação de trem integrada ao metrô, que leva boa parte dos torcedores que vão ao novo estádio, apelidado de Engenhão, legado dos Jogos Pan- Americanos de 2007. No entanto a integração com a estação de trem não foi bem planejada e causa aglomerações.

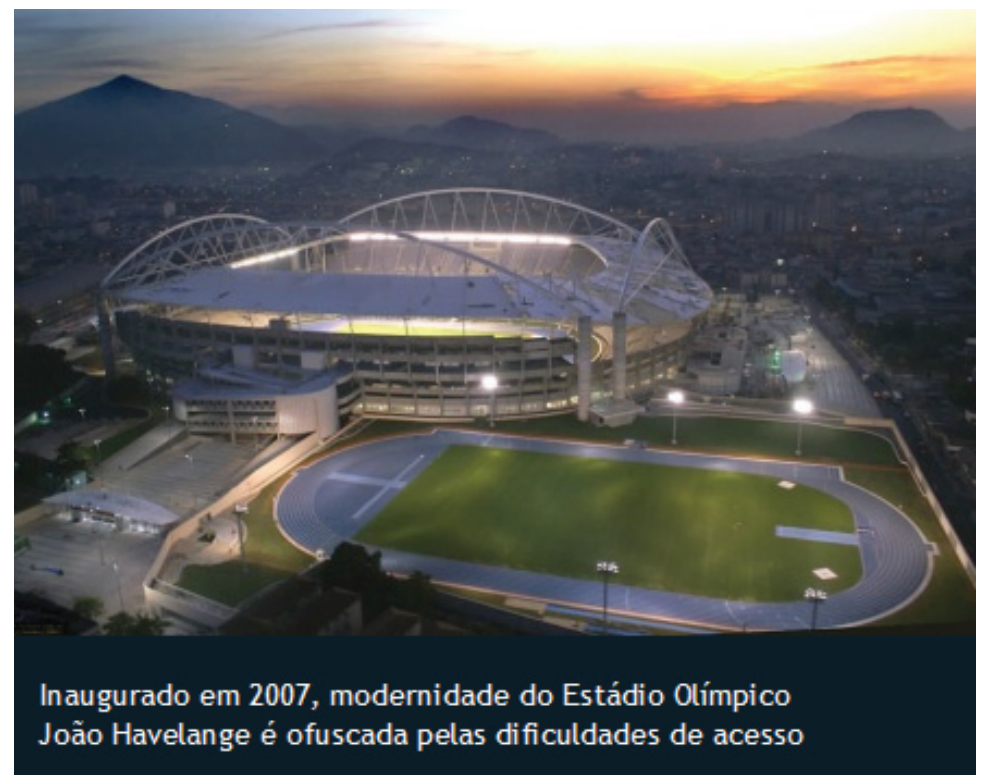

Figura 19: O Engenhão, em Deodoro. Fonte: Site R713

Quem opta pelo automóvel enfrenta engarrafamentos e dificuldades para estacionar (o estádio tem 1.660 vagas). Como referência de boas práticas, tem-se os Jogos Olímpicos de Londres, em que os usuários eram incentivados a usar o metrô, o trem e bicicletas para ter acesso ao local. Os estádios foram projetados com poucas vagas e, mesmo durante as obras, as equipes envolvidas chegavam ao local em transporte público.

Foi-nos relatado, por usuário do ramal da Supervia que passa por Deodoro, que vários dos novos vagões coreanos estão parados, enquanto os antigos continuam operando, sem condições de conforto. No site da empresa, não há informações a esse respeito. É urgente a adaptação das vias de trem, estações e vagões, para que tenham a qualidade do metrô, e que ambos os sistemas tenham vagões e linhas projetadas para a demanda atual e futura.

E no estádio do Maracanã, um dos símbolos cariocas, está previsto trocar pistas de atletismo e parque aquático por garagens com capacidade para 2000 vagas. A informação está no jornal eletrônico O Dia ${ }^{14}$, de 23 de outubro de 2012.

$12 \mathrm{http}: / /$ rio2016.org/search/node?search_text=legado

$13 \mathrm{http}: / /$ noticias.r7.com/rio-de-janeiro/noticias/r7-testou-conheca-os-caminhos-para-o-engenhao-20101002.html

14 http://odia.ig.com.br/portal/rio/maraca-gestor-vai-derrubar-pista-e-parque-aqu\%C3\%A1tico-1.505972 


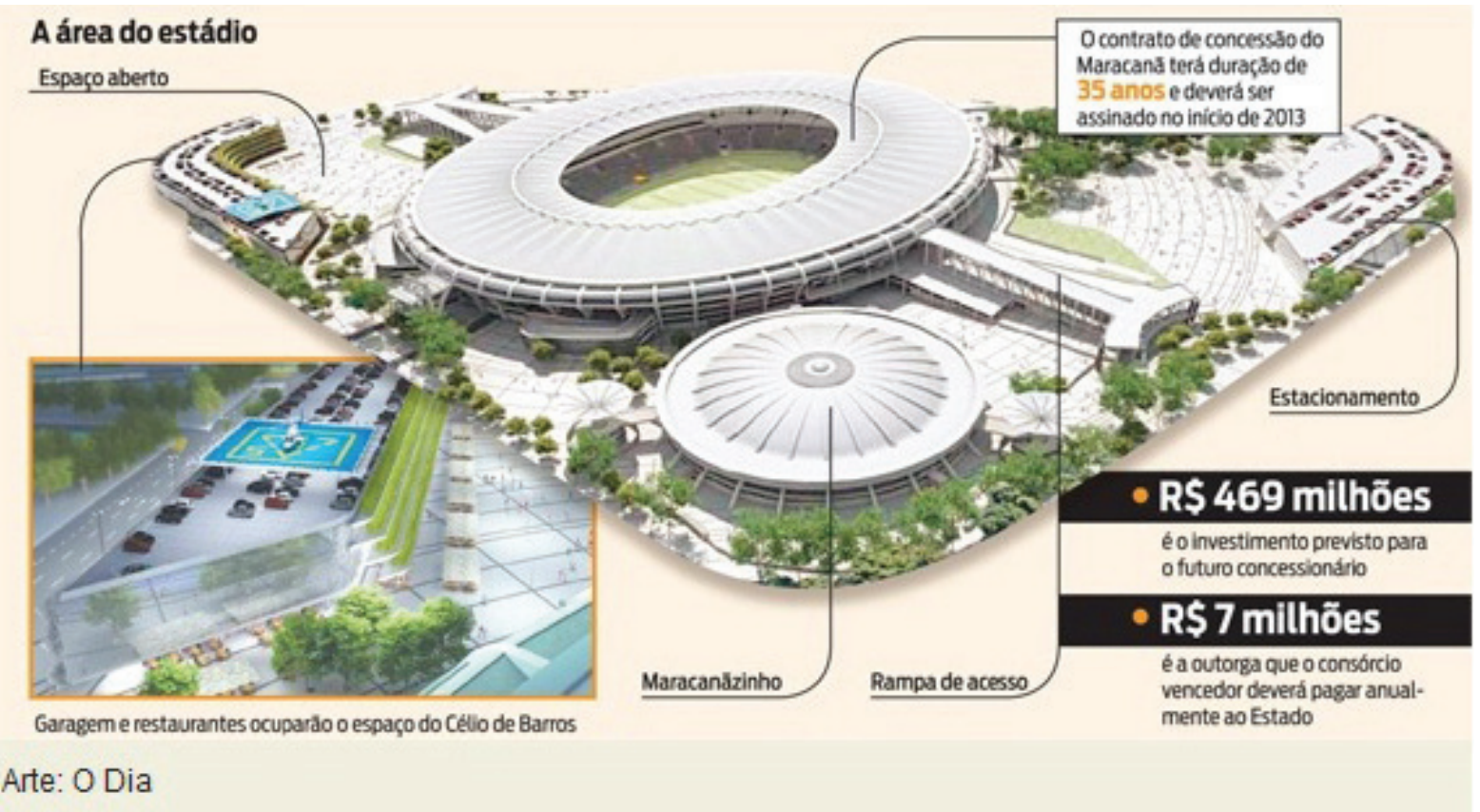

Figura 20: Trocar área de esporte por garagens e restaurantes.

\section{As novidades do complexo}

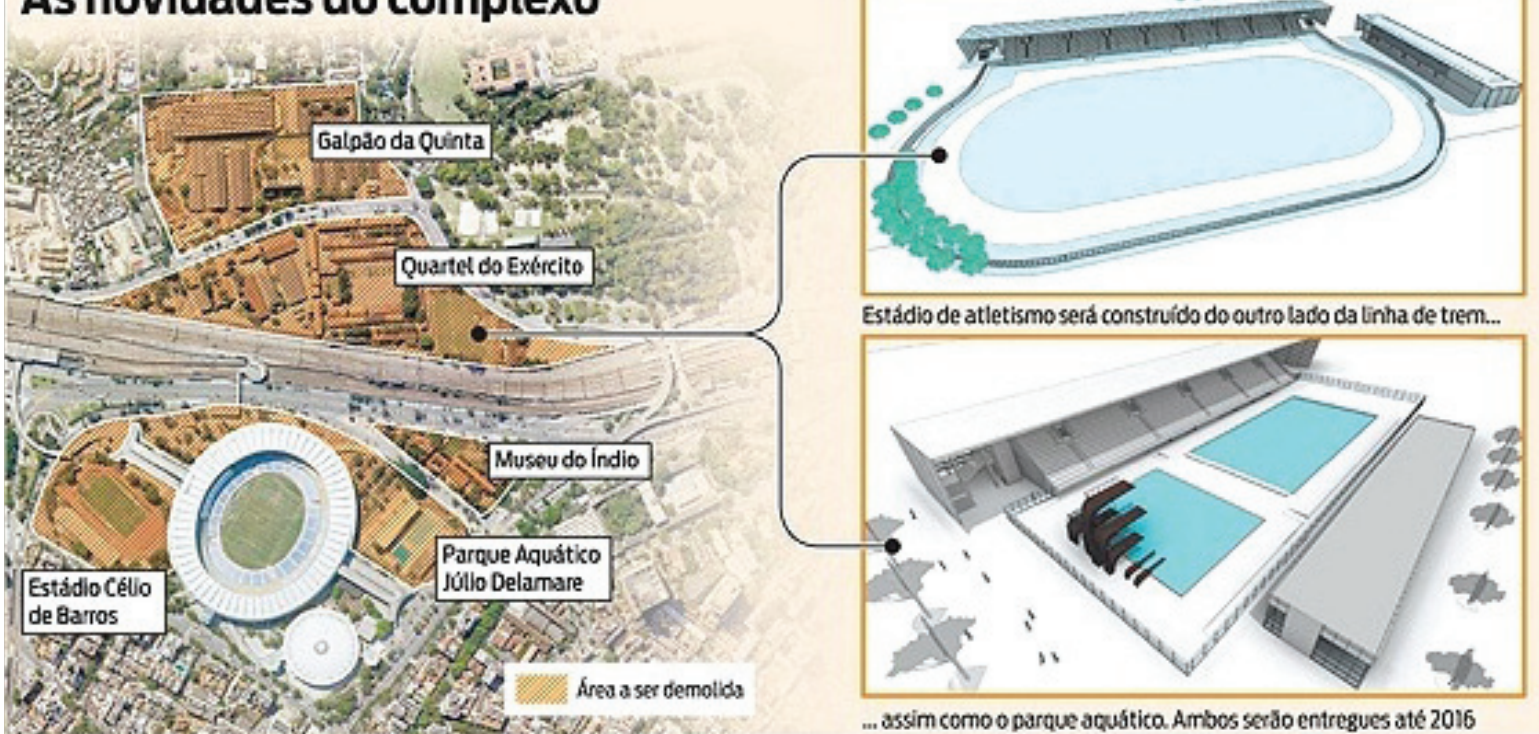

Arte: O Dia

Figura 21: Novas pistas de atletismo e piscinas.

Novo estádio de atletismo e parque aquático são projetados, do outro lado da Av. Radial Oeste, mas não há informações sobre estacionamentos. Digamos que outras mil vagas sejam projetadas. Estímulo à indústria automobilística, ao lado de uma linha 
de trem e metrô integrado. A reportagem informa também sobre manifestações contra a demolição do Museu do Índio, vizinho ao estádio, para dar lugar a mais vagas. Estacionamentos para bicicletas não foram cogitados, apesar de nova ciclovia ligar a estação de metrô Saens Pena ao estádio.

Para facilitar o deslocamento da família Olímpica, informação do jornal O Globo desta semana ${ }^{15}$ relata que a prefeitura estuda a construção de túnel, como alternativa a uma terceira faixa para automóveis no elevado do Joá, uma das ligações entre a zona sul da cidade e a Barra da Tijuca. Segundo a reportagem, as melhorias no Joá seriam um dos legados olímpicos para o Rio. Já conforme as diretrizes de mobilidade sustentável, o enfoque deveria ser em transporte público de qualidade, para que, justamente, menos pessoas precisassem usar automóveis em seus deslocamentos diários.

$\mathrm{Na}$ Barra da Tijuca, conforme o portal da prefeitura, além dos equipamentos esportivos previstos para os Jogos Olímpicos, as prioridades são programas de recuperação de parques e redes fluviais.

Barcos movidos a energia solar poderiam fazer parte dos projetos de mobilidade, aproveitando as redes fluviais. Visando a mobilidade em um bairro planejado para deslocamentos em automóvel, preconiza-se a construção de passarelas-jardim, largas o suficiente para permitir a circulação confortável de pedestres e ciclistas, além de jardins e equipamentos urbanos, criando ligações seguras sobre a Av. das Américas, em alguns pontos estratégicos, associados a rebaixos nas vias para reduzir a altura das passarelas, onde hoje moradores de grandes condomínios usam o carro para levar seus filhos à escola ou para ir ao shopping, do outro lado da avenida. Ciclovias e calçadas arborizadas e seguras, próximas às edificações, seriam também bem-vindas. Investimentos que seguramente gerariam benefícios, como o exemplo de Londres, citado na introdução deste artigo.

Ainda na Barra da Tijuca, um campo de golfe com cerca de um milhão de metros quadrados, para atender às especificações olímpicas, foi escolhido em concurso público. A questão está gerando polêmica, por estar em Área de Preservação Ambiental, e fazer parte de acordo liberando também a construção de 22 blocos de apartamentos com 22 andares. Certamente, todos terão vagas para carros. Espera-se que os vencedores do

15 31.10.2012, p. 14 - Um plano B pra o Joá. 
concurso tenham pensado no legado e previsto transformação do uso em parque público, após os jogos, e que os empreendedores dos novos apartamentos invistam em infraestrutura para mobilidade de todos, como forma de compensação ambiental.

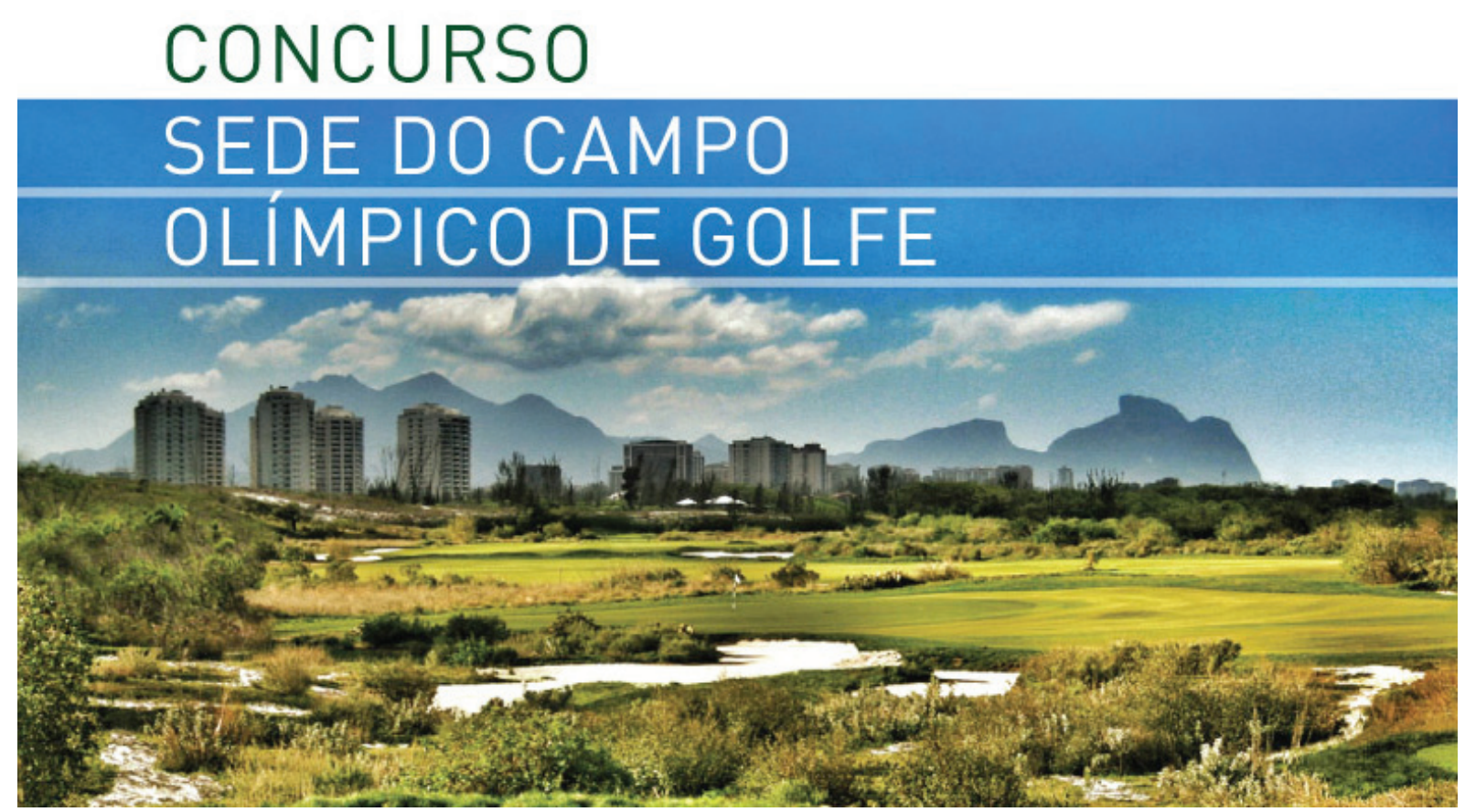

Figura 22: Imagem IAB RJ, convite para a cerimônia de premiação.

\section{CONCLUSÃO}

Em termos de mobilidade urbana sustentável, a cidade do Rio de Janeiro terá avançado, após os eventos esportivos, mas ainda haverá muito a avançar. A maioria das diretrizes, características e critérios apontados por especialistas, não foram sequer considerados. Alguns exemplos destacados:

Sistema de BRT - Problemas de gerenciamento, ônibus vazios ou superlotados, acidentes em travessias, falta de investimento simultâneo em transporte não motorizado. A alegação de custo alto para investimento em transporte de maior capacidade não é coerente com um investimento de bilhões para demolição do viaduto da Perimetral, por exemplo. Não foram atendidas as diretrizes para projetar o conforto urbano por meio de arborização, travessias, calçadas e vias para ciclos adequadas ao local de implantação; para promover a figura do gestor de mobilidade e a integração entre os diversos atores envolvidos nas ações de gerenciamento; não se teve em conta que 
todo novo investimento em transporte motorizado deve prever o mesmo valor investido em transporte não motorizado.

Porto Maravilha - Não foram atendidas as diretrizes para substituir a lógica da expansão (mais vias) pela gestão e integração (melhores vias para todos); mudar o conceito de bicicleta como artigo de esporte, incentivar empresas a usar a integração metrô-bicicleta como meio de transporte, criar bicicletários em metrôs, e vestiários em fábricas e prédios comerciais, destacando o conceito da saúde para o usuário e para o planeta; projetar novas expansões urbanas a partir de exemplos bem sucedidos, adaptando-os às condições espaciais, econômicas e sociais do local, incentivando integração e inclusão social.

Maracanã - Modernizar o estádio com painéis fotovoltaicos ${ }^{16}$, que vão gerar energia para sua operação e manutenção, é contribuir com economia de energia, investimento que se paga com o uso. Se, com a recente reforma, o estádio terá capacidade para cerca de 78.800 espectadores, as novas duas mil vagas para automóveis poderiam ser no antigo quartel do exército, e o investimento maior seria nas integrações da estação local de metrô/trem com outros modais, e aplicação do conceito de passarela-jardim, criando "corredores verdes", ligando o estacionamento e a Quinta da Boa Vista, com o Maracanã e a grande Tijuca. Ligando pessoas e biodiversidade. Menos engarrafamentos, acidentes, poluição do ar e sonora.

Não foram atendidas as diretrizes para preservar, defender e promover, nos projetos e políticas públicas voltadas ao transporte público e à circulação urbana, a qualidade do ambiente natural e construído e o patrimônio histórico, cultural e artístico das cidades; projetar soluções para estacionamentos dos diversos modais de transporte, visando a equidade; promover ligações diretas, privilegiando a mobilidade não motorizada, integrando atividades e localidades.

Espera-se que algumas destas diretrizes possam ainda ser atendidas, e que o movimento em busca do desenvolvimento sustentável supere o estilo internacional preconizado pela Carta de Atenas.

16 http://www.estadao.com.br/especiais/maracana-fica-mais-moderno-sem-abrir-mao-de-suahistoria,182163.htm 


\section{REFERÊNCIAS BIBLIOGRÁFICAS}

BODMER, M. \& MARTINS, J. (2005). Propostas de políticas integradas de uso do solo e transporte. Brasília: Universa. (Série Planejamento e Gestão Ambiental, n. 7. Fundamentos conceituais do planejamento e gestão ambiental.)

BROWN, L. (2003). Eco economia. Uma nova economia para a Terra. Earth Policy Institut. Disponível em: < http://www.wwiuma.org.br/ eco_download.htm >. Acesso em: out. de 2012.

CHOAY, F. (1965). O urbanismo: Utopias e realidades, uma antologia. (Trad. de Dafne Nascimento Rodriguez.) 5 ed. São Paulo: Perspectiva, 2003.

COM (2004). Para uma estratégia temática sobre ambiente urbano. Comissão das Comunidades Europeias. Disponível em: <http://eur-lex.europa.eu/LexUriServ/site/pt/ com/2004/com2004_0060pt01.pdf>. Acesso em: out. 2012.

CRAWFORD, J. (2006). Car free cities. Disponível em: <http://carfree.com/topology. html>. Acesso em: outubro de 2012.

ESTEVES, R.. Cenários urbanos e Traffic Calming. Tese (D.Sc.) - Programa de Engenharia de Produção - COPPE-UFRJ. Rio de Janeiro, 2003.

GUIMARÃES, P. P. Configuração urbana: Evolução, avaliação, planejamento e urbanização. São Paulo: ProLivros, 2004.

HEIERLI, U.. Environmental limits to motorization. Nova Delhi: Har-Anand Publications, 1995.

HERZOG, C. (2010). Teorias e práticas em construção e compras públicas sustentáveis. Seção IV, 3. Infraestrutura verde para cidades mais sustentáveis. Disponível em: $<w w w$.iclei.org/ccps-rj> ou Cadernos Virtuais de Construção Sustentável < http://www. rj.gov.br/web/sea/exibeConteudo?articleid=373573> Acesso em: outubro 2012.
ILLICH, I. (1973) Energia e equidade. In: Apocalipse motorizado. A tirania do automóvel em um planeta poluído. São Paulo: Conrad Editora do Brasil, 2004. p. 33- 71.

ITDP, Gehl Architects (2010). Our cities, ourselves: The future of transportation in urban life. Disponível em: http://www.itdp.org/ documents/2010-OurCitiesOurselves_Booklet.pdf Acesso em outubro de 2012.

LINDQUIST, E. (1998). Moving toward sustainability: Transforming a comprehensive land use and transportation plan. Transportation Research Record, 1617, n. 98-0538.

LITMAN, T. (2003). Active transportation policy issues. Canadá: Victoria Transport Police Institute. Disponível em: <http:www.vtpi. org>. Acesso em: 15 de novembro de 2003.

LUDD, N. (Org.). Apocalipse motorizado. A tirania do automóvel em um planeta poluído. São Paulo: Conrad Editora do Brasil, 2004.

NILSSON, P. K. (1998). Best practice to promote walking and cycling. Holanda: Projeto ADONIS e SWOV/Institute of Road Safety Research. Disponível em: <www.cities-forcyclists.org/dokumenter/adonis.pdf>. Acesso em: 3 julho 2004.

PORTLANDONLINE (2006). Transportation services. Disponível em: <http://www. portlandonline.com/transportation/index. $\mathrm{cfm} ? \mathrm{c}=35728>$. Acesso em: 15 de setembro de 2006.

ROSA, L. Z. Parque vivencial como ferramenta educacional de incentivo à mobilidade sustentável. Tese (D.Sc.) - Programa de Engenharia de Transportes - COPPEUFRJ. Rio de Janeiro, 2007.

VALLEJO, M. \& TORNER, F. La ingeniería en la evolución de la urbanística. Barcelona: Ed. Universidade Politécnica da Catalunha, 2002. 